\title{
The Effects of Papain Crude Extract Addition in Diets on Broilers Production Performances
}

\author{
Laurentius Rumokoy, Endang Pudjihastuti, Ivonne Maria Untu, Wisje Lusia Toar \\ Department of Nutrition and Feed Sciences, Faculty of Animal Husbandry, Sam Ratulangi University, Jalan Kampus \\ Unsrat, Manado 95115, Indonesia \\ Corresponding author email: rumokoy@msn.com
}

\begin{abstract}
This study was conducted to evaluate the effects of papain crude extract addition in mash and pellet feed forms on production performance of broiler chickens in order to obtain the best level of extract papain in mash or pellet form. This natural protease enzyme was extracted from unripe papaya. A complete random design was applied in this study and it was arranged with factorial $4 * 2$ and three replications. The treatments were 4 levels of papain $(0,0.03,0.05$, and $0.07 \%)$ and two physical forms of feed (mash and pellet). Broilers production parameters measured were: feed intake, body weight, feed conversion ratio (FCR) and carcass percentage. The results of analysis of variance showed that the interaction was highly significant $(P<0.01)$ for feed intake, body weight, carcass percentage respectively while feed conversions have significant interaction $(P<0.05)$. The significant differences in the feed consumption described the role of papain enzyme through treatment of CEP and the physical form of feed. The results indicate that the all treatment of papain crude extract level both in mash and pellet feed form were able to improve feed intake, body weight, FCR and carcass percentage of broiler chickens, whereas the best performance was obtained in the treatment of $0.05 \%$ papain crude extract in mash form of diets.
\end{abstract}

Key words: papain, FCR, carcass, mash, pellet

Abstrak. Penelitian ini dilakukan untuk mengetahui lebih dalam efek penambahan ekstrak kasar papain dalam pakan berbentuk mash dan pellet terhadap penampilan produksi broiler. Enzim protease alami ini diekstrak dari pepaya muda. Rancangan acak lengkap diterapkan dalam penelitian ini yang disusun secara faktorial $4 * 2$ dan tiga ulangan. Perlakuan yang diberikan adalah 4 tingkatan papain $(0,0,03,0,05$, dan $0,07 \%)$ dan dua bentuk fisik pakan (mash dan pelet). Parameter poduksi broiler yang diukur adalah konsumsi pakan, berat badan, rasio konversi pakan (FCR) dan persentase karkas. Hasil analisis varians menunjukkan ada interaksi yang sangat signifikan $(P<0,01)$ menyangkut konsumsi pakan, berat badan dan persentase karkas masing-masing, sementara konversi pakan menunjukkan interaksi yang nyata $(P<0,05)$. Perbedaan yang signifikan dalam konsumsi pakan menggambarkan peran enzim papain melalui perlakuan CEP dan bentuk fisik pakan. Hasil menunjukkan bahwa semua perlakuan tingkat ekstrak kasar papain baik di mash dan pakan pelet bentuk mampu meningkatkan konsumsi pakan, berat badan, FCR dan persentase karkas ayam broiler, sedangkan performan terbaik diperoleh pada perlakuan 0,05\% papain ekstrak kasar dalam pakan berbentuk mash.

Kata kunci: papain, konversi pakan, karkas, mash, pellet

\section{Introduction}

Production of broiler chickens is determined by feed quality among various factors. Although nutrients content in the diet has been qualified as a balanced nutrient, various supporting factors are also important such as particle size and feed form to affect the broilers' performances production. The role of papain extracted from unripe papaya fruits as an exogenous enzymes can be used to simplify the nutrients when absorbing digestive tract in the chicken gut, while until know there has not reached yet a precise level of papain crude extract recommended to be applied in animal nutrition for broiler production improvement. Therefore, it is necessary to reveal the best concentration of crude papain extract to be used as an organic supplement either in mash form or pellet form of feed to support the production of broiler chickens. 
This papain crude extract is a proteolytic enzyme that can break down peptide bonds of a protein molecule (Aravind et al., 2013).The papain crude extract typically derived from the sap of unripe papaya fruits (Li et al., 2010; Jeana et al., 2013; Nitsawang et al., 2006) or from papaya latex which can be collected directly from the fruit which are still hanging on the tree (Macalood et al.,2013). An application of papain in rations for poultry has been studied by Kanyinji and Zulu (2014) showed an improvement on feed conversion. Other researchers used papaya leaf as a source of papain other than crude extract from the sap of the papaya fruit. Sudjatinah et al. (2009) reported the use of papaya leaf extract to be mixed into the feed of poultry until a concentration of $25 \mathrm{ml}$ per liter of drinking water has not shown any significant influence on performance of broiler production. Widjastuti (2009) used the papaya leaf meal up to $10 \%$ in layer rations did not provide a significant effect on the quality of the eggs production.

\section{Materials and Method}

\section{Experimental Broilers and Treatments.}

Ninety-six male broiler chickens, starting from day old chick (DOC) until six week of age, were housed in 24 pens (four chicken in each pen) with a dimension of $70 \times 70 \times 75 \mathrm{~cm}$. All pens were equipped with feeders and drinkers. At the first weeks the animals received the heater lamp and the temperature was controlled according to animal growth. The chickens were randomly divided in eight treatments combination using the completely randomized design in $4 \times 2$ factorial arrangement of 8 treatments with three replications. The factors were physical form of diets: mash and pellet and crude papain extract level $0,0.03,0.05$, and $0.07 \%$ of feed. Feed and water were offered $a d$ libitum.

\section{Parameters Measured and Feed Preparation}

The parameters of broiler production under the treatments effects were feed intake, body weight, feed conversion ratio (FCR), and carcass presentation. Both mash and pellet feed form were formulated by using the ingredients as shown in table 1 and the feed were added with crude papain extract according to the level of treatments, excepted in the control $(0.00 \%)$. After adding and mixing the substances of papain crude extract in the ingredient then the pellet and mash form were produced. The pellet forms were produced by using a pelleting machine under a temperature of $40 \stackrel{\circ}{\circ}$. To avoid the enzymes denaturation all diets were formulated and produced each day before distributing to the chickens. Live body weight, feed intake, weight gain and feed conversion ratio were calculated weekly from the $1^{\text {st }}$ to $6^{\text {th }}$ week. At the end of experiment, two birds per treatments were slaughtered for carcass measurements.

Feed Ingredient and Nutrients: The nutrients composition of ingredient, as shown in table 1 , while the content of amino acids in papain crude extract used in this experiment is presented in table 2 .

\section{Results and Discussion}

The proximate of nutrients composition of diets is presented in table3. The two types of diets were formulated regarding to the age of broiler chickens: the diets along 0 to 3 weeks and then 3 to 6 weeks of ages.

This results showed that all treatment level of papain crude extract $(0.03,0.05$ and $0.07 \%)$ improved a better value for BW, FCR and carcass performances of broilers than the performances of animals consumed the diets without any papain both in mash and pellet form. It revealed also that the interaction of papain crude extract and feed form were significant for feed intake, body weight, feed conversion ratio, and carcass percentage throughout observation. 
Table1. Chemical composition of raw materials*

\begin{tabular}{lcccccc}
\hline Ingredients & $\begin{array}{c}\text { ME } \\
\text { (Kcal/kg) }\end{array}$ & CP & CF & Lipid & Calcium & Phosphor \\
\hline Yellow corn & 3350 & 8.5 & 2.2 & 3.8 & 0.02 & 0.28 \\
Rice bran & 2980 & 12.9 & 11.4 & 13.0 & 0.07 & 0.22 \\
Soybean cake & 2230 & 44.0 & 7.0 & 0.8 & 0.29 & 0.65 \\
Fish meal & 2820 & 60.0 & 0.7 & 9.4 & 5.11 & 2.88 \\
Coconut oil & 8600 & & & 100 & & 12.5 \\
Bone meal & & & & & 29.8 & 35 \\
Chalk & & & & & & \\
\hline
\end{tabular}

* The calculation based on proximate analysis

Table 2. Amino acids content in crude extract papain

\begin{tabular}{lc}
\hline Amino acids & Concentration (\%) \\
\hline Arginine & 5.70 \\
Glycine & 9.82 \\
Histidin & 0.95 \\
Leucine & 4.09 \\
Isoleucine & 5.50 \\
Lysine & 4.52 \\
Methionine & - \\
Cysteine & 2.83 \\
Phenylalanine & 1.65 \\
Threonine & 2.88 \\
Tryptophan & 2.20 \\
Valine & 7.45 \\
Tyrosine & 4.68
\end{tabular}

*The amino acids of crude papain extract calculation was based on laboratory analysis

The benefit values of papain crude extract expressed in all parameters were significantly higher than in control both in mash and pellet feed forms. The addition of papain crude extract as exogenous protease source in mash diets increased significantly feed intake compared to the control. The same performance for feed intake in pellet form showed a significant increasing according to the treatment of this crude extract compared to control. The highest average $(3,244 \mathrm{~g})$ of feed intake of broiler discovered in treatment of papain crude extract at $0.05 \%$ added in mash form while the lowest average of feed intake $1,983 \mathrm{~g}$ found in the crude papain up to $0.03 \%$ applied in pellet form. The positive effect of crude papain was appeared also for body weight of chickens which had received papain crude extract in each level compared to the control. The addition of papain in pellet form tended to provide a lower on body weight of broilers than the addition in mash form. This was linked to broiler feed intake that were more high by consuming the diet with a mash form than in the pellet form.

\section{Results and Discussion}

The performances values of broilers as provided in this study: body weight, feed intake, carcass percentage and feed conversion ratio. By its results enabled us to decide which level of papain treatment was the best either in mash or pellet form. The papain extract influenced a higher palatability both in mash and pellet followed by the positive response on body weight, consequently it affected the feed intake and in the same time feed form affect broiler productions. Amerah et al. (2007) has similar results with Kanyinji and Zulu (2014) that confirmed the increasing of feed intake led a better body weight gain by using papain extracted from papaya plant in the diets. Ahmed and Abas (2013) demonstrated broiler feed intake was higher in mash than in pellet. This performance caused by the particle size and feed form (Chewning et al., 2012; Ebrahimi et al., 2010). Furthermore the significance of interaction of papain crude extract and feed forms for feed conversion ratio (FCR) throughout the observation affirmed the role of crude papain application levels up to $0.07 \%$ in diets. Several previous researchers observed 
the role of supplementation of protease in the $\operatorname{diet}($ Vieira et al., 2013) resulted a better feed intake (Mahejabin et al., 2015), body weight and FCR values to the chicken (Kame et al., 2015). This condition facilitated digestibility of amino acids in the diets to get a better FCR of broilers (Mejia et al., 2011). Similar response was reported by Yadav and Sah (2006)the use of $0.07 \%$ and $0.1 \%$ acid protease in diets improved the feed efficiency of layer chicken, while Rada et al.(2013)was divergent showed that the exogenous mono-component protease added into low protein broiler diet had no significant effect on both observed growth parameters carcass characteristic. The results described that the use of crude papain extract in broilers diets both through mash and pellets feed form could improve FCR although the pellet diet was less able to rise FCR than the smash diet. This state seems triggered by decreasing of papain function in pellet when passed through the pelleting process under temperature about 40 o $\mathrm{C}$ which reduced the papain activity. The treatment effects observed on broiler production performances are shown in table 4.

The variance analysis indicated a significant effect $(P<0.01)$ of treatment combination of crude papain levels and feed forms on broilers carcass percentage. The interaction of mash feed form with each level of papain gave a higher average of carcass percentage than in the form of pellets. The similar effect of feed form has been investigated by Corzo et al.(2012) and Cerrate et al. (2009) which related to difference size mash compared to pellet form (Abdollahi et al., 2012; Zohair et al., 2012 and Dozier et al., 2010). The highest carcass percentage was significant obtained from broilers received the treatment of mash form combined with crude papain $0.05 \%$, while the lowest response of this parameter was revealed in the broilers consumed pellet feed form with crude papain $0.07 \%$ addition. The response of a lower of body weight in broilers that consumed pellet diets than mash with crude papain addition seems related to the decreasing role of papain in pellet. Amirabdollahian et al. (2014); Creswell and Bedford (2006) stated that pelleting temperature is a limit factor that effect on pellet quality. Beside that enzyme feed particle size contributed also to the quality of diets as reported by Attia et al. (2014); Rezaeipour and Gazani (2014) and Aderibigbe et al. (2013).

Table 3.Composition and calculated analysis of the diets (\%) according to chicken age

\begin{tabular}{|c|c|c|}
\hline Composition of Diets & $\begin{array}{l}0 \text { to } 3 \\
\text { weeks }\end{array}$ & 3 to 6 weeks \\
\hline \multicolumn{3}{|l|}{ Ingredients } \\
\hline \multirow{2}{*}{\multicolumn{3}{|c|}{$\begin{array}{l}\text { Extract papain } \\
\text { supplementation }\end{array}$}} \\
\hline & & \\
\hline Yellow corn & 60 & 55 \\
\hline Rice bran & 4 & 14 \\
\hline Soybean cake & 25 & 20 \\
\hline Fish meal & 7.5 & 3.45 \\
\hline Coconut oil & 0.25 & 1 \\
\hline Bone Meal & 0.5 & 4 \\
\hline Premix A & 0.5 & 2 \\
\hline Methionine & 0.5 & 0.2 \\
\hline Chalk & 0.2 & 0.35 \\
\hline \multicolumn{3}{|l|}{$\begin{array}{l}\text { Calculated nutrients } \\
\text { composition }\end{array}$} \\
\hline Metabolic energy & 3091 & 2888 \\
\hline Crude Protein & 21 & 17 \\
\hline Lipids & 5.9 & 5.2 \\
\hline Crude Fiber & 3.6 & 4.0 \\
\hline Calcium & 0.68 & 2.1 \\
\hline Phosphor & 0.61 & 0.9 \\
\hline Arginine & 1.3 & 1.1 \\
\hline Glycine & 0.97 & 0.78 \\
\hline Histidine & 0.65 & 0.46 \\
\hline Leucine & 1.85 & 1.52 \\
\hline Isoleucine & 0.91 & 0.72 \\
\hline Lysine & 1.23 & 0.93 \\
\hline Methionine & 0.46 & 0.47 \\
\hline Sistine & 0.32 & 0.28 \\
\hline Phenylalanine & 0.99 & 0.81 \\
\hline Threonine & 1.83 & 1.36 \\
\hline Tryptophan & 0.28 & 0.22 \\
\hline Valine & 1.04 & 0.84 \\
\hline Tyrosine & 0.84 & 0.68 \\
\hline
\end{tabular}

*The calculation of nutrient values of diets was based on laboratory as approximate analysis 
Table 4. Treatment effects on broiler production performance

\begin{tabular}{|c|c|c|c|c|c|c|c|c|c|}
\hline \multirow{2}{*}{$\begin{array}{l}\text { Papain crude } \\
\text { extract } \\
\text { Supplementation }\end{array}$} & \multicolumn{4}{|c|}{ Mash } & \multicolumn{4}{|c|}{ Pellet } & \multirow[b]{2}{*}{$P$} \\
\hline & 0.00 & 0.03 & 0.05 & 0.07 & 0.00 & 0.03 & 0.05 & 0.07 & \\
\hline \multicolumn{10}{|l|}{ Parameters: } \\
\hline Initial BW (g) & 43 & 43 & 43 & 43 & 43 & 43 & 43 & 43 & \\
\hline Feed Intake (kg) & $2.69^{e}$ & $2.83^{f}$ & $3.24^{h}$ & $3.07^{\mathrm{g}}$ & $1.98^{\mathrm{a}}$ & $2.55^{d}$ & $2.33^{c}$ & $2.21^{b}$ & $<0.01$ \\
\hline $\mathrm{BW}(\mathrm{kg})$ & $1.42^{\mathrm{e}}$ & $1.51^{f}$ & $1.79^{h}$ & $1.67^{\mathrm{g}}$ & $0.99^{a}$ & $1.34^{d}$ & $1.20^{c}$ & $1.12^{b}$ & $<0.01$ \\
\hline FCR $(\mathrm{g} / \mathrm{g})$ & $1.90^{\mathrm{cd}}$ & $1.87^{\mathrm{bc}}$ & $1.81^{\mathrm{a}}$ & $1.84^{\mathrm{ab}}$ & $2.00^{f}$ & $1.91^{\mathrm{cd}}$ & $1.94^{\text {de }}$ & $1.97^{\mathrm{ef}}$ & $<0.05$ \\
\hline Carcass (\%) & $59.5^{b c}$ & $62.3^{\mathrm{cd}}$ & $69.8^{e}$ & $63.3^{d}$ & $53.0^{\mathrm{a}}$ & $58.6^{b}$ & $58.0^{b}$ & $54.7^{a}$ & $<0.01$ \\
\hline
\end{tabular}

abc Means in the same row without common letter are different at $\mathrm{P}<0.05$

Through this works, it can be summarized that papain crude extract added in mash and pellet form are suitable to improve the broiler production performance, and to get the best performance it should be considered the temperature in pelleting processing to avoid the reducing of crude papain function in the diets of broilers.

\section{Conclusions}

The best level of papain crude extract was at $0.05 \%$ in mash form of diets to increase the broilers performances for feed intake, body weight, feed conversion ratio and carcass production. When the broilers consumed diets with addition of papain crude extract in mash form resulted a better production performances than those consumed pellet form with papain crude extract addition.

\section{Acknowledgment}

This research was supported by a financial aid from "Kompas" newsletter in Jakarta Indonesia. As the authors, we are very grateful for this meaningful support.

\section{References}

Abdollahi MR, V Ravindran, TJ Wester, G Ravindran and DV Thomas. 2012. The effect of manipulation of pellet size (diameter and length) on pellet quality and performance, apparent metabolisable energy and ileal nutrient digestibility in broilers fed maize-based diets. Animal Production Science 53(2):114-120.

Aderibigbe OB, OM Sogunle, LT Egbeyale, SS Abiola, AO Ladokun and OLAjayi. 2013. Pelletized feed of different particle sizes: effects on performance, carcass characteristics and intestinal morphology of two strains of broiler chicken. Pertanika J. Trop. Agric. Sci.36(2013):127-144.

Ahmed ME and TE Abbas. 2013. The Effect of Feeding Pellets versus Mash on Performance and Carcass Characteristics of Broiler Chicks. Bull. Env. Pharmacol. Life Sci. 2(2):31- 34

Amirabdollahian $\mathrm{H}$, AN Nouri Emamzadeh, $\mathrm{K}$ Keramatiand and RR Koochaksaraie. 2014. A comparative effect of mash and pellet feed with different pelleting temperature on blood metabolites, carcass charateristics and broiler performance. The $1^{\text {st }}$ International Conference on New Ideas in Agriculture, Islamic Azad University Khorasgan Brach.26 - 27 January 2014, Isfahan, Iran.

Amerah AM, V Ravindran, RG Lentleand and DGThomas.2007. Influence of feed particle size and feed form on the performance, energy utilization, digestive tract development, and digesta parameters of broiler starters. Poult. Sci. 86:2615-2623.

Angel CR, W Saylor, SL Vieiraand and N Ward. 2011. Effects of a monocomponent protease on performance and protein utilization in 7- to 22day-old broiler chickens. Poultry Science. 90: 2281-2286.

Aravind G, DBhowmik, S Duraivel and G Harish. 2013. Traditional and Medicinal Uses of Carica papaya. Journal of Medicinal Plants Studies. 1:715.

Attia YA, WS El-Tahawy, E Abd El-Hamid, El-Hamid, A Nizza, F Bover, MA Al-Harthi and MI El-Kelway. 2014.Effect of feed form, pellet diameter and enzymes supplementation on growth 
performance and nutrient digestibility of broiler during days 21-37 of age.

Buchanan NP, KGS Lilly, CK Gehring and JS Moritz.2010. The effects of altering diet formulation and manufacturing technique on pellet quality. J. Appl. Poult. Res. 19:112 - 120.

Cerrate S, Z Wang, C Coto, F Yan and PW Waldroup. 2009. Effect of pellet diameter in broiler starter diets on subsequent performance. J. Appl.Poult. Res. 18:590-597.

Chewning CG, CR Stark and J Brake. 2012. Effects of particle size and feed form on broiler performance. J. Appl. Poult. Res. 21:830-837.

Corzo A, L Mejia, CD McDaniel and JS Moritz. 2012. Interactive effects of feed form and dietary lysine on growth responses of commercial broiler chicks. J. appl. Poult. res. 21:70-78.

Creswell D and M Bedford. 2006. High pelleting temperatures reduce broiler performance. Proc. Aust.Poult. Sci.Symp. 18(2006):1-6.

Dozier WA, KC Behnke, CK Gehring and SL Branton. 2010. Effects of feed form on growth performance and processing yields of broiler chickens during a 42-day production period. J. Appl.Poult. Res. 19:219-226.

Ebrahimi R, MBojar Pour and MS Zadeh. 2010. Effect of feed particle size on the performance and carcass characteristics of broilers. Int. J. Anim. Vet. Adv. 9(10):1482-1484.

Macalood JS, HJ Vicente, RD Boniao, JG Gorospe and EC Roa.2013. Chemical Analysis of Carica papaya L. Crude Latex. American Journal of Plant Sciences. 4:1941-1948.

Kamel NF, M Naela, RA Ragaa, El-Banna and FF Mohamed. 2015. Effects of a Monocomponent Protease on Performance Parameters and Protein Digestibility in Broiler Chickens. Agriculture and agricultural procedia. 6:216-255.

Kanyinji F and C Zulu. 2014. Effects of Partially Replacing Soybean Meal in Grower Diets with Pawpaw (Carica papaya) Leaf Meal on Nutrient Digestibility and Growth Performance of Japanese Quails (Cortunix japonica). International Journal of Livestock Research. 4(5):7-14.

Li M, E Su, P You, X Gong, M Sun, D Xu and D Wei. 2010. Purification and In Situ Immobilization of Papain with Aqueous Two-Phase System. PLoS One. 5(12): e15168.
Macalood JS, HJ Vicente, RD Boniao, JG Gorospe and EC Roa. 2013.Chemical Analysis of Carica papaya L. Crude Latex. American Journal of Plant Sciences. 4:1941-1948.

Mahejabin N, M Mostofa, F Akter, S Das and M Alam. 2015. Effects of Neem, turmeric and papaya leaf extract mixture on growth performance of broilers. International Journal of Natural and Social Sciences. 2(2015):17-21.

Mejia L, CD Zumwalt, EJ Kim, PB Tillman PB and A Corzo. 2011. Digestible isoleucine-to-lysine ratio effects in diets for broilers from 4 to 6 weeks posthatch. J. Appl.Poult. Res. 20(4):485-490.

Nitsawang S, R Hati-Kaul and P Kanasaud. 2006. Purification of papain from Carica papaya latex: Aqueous two-phase extraction versus two-step salt precipitation. Enzyme and microbial Technology. 39(5):1103-1107.

Rada V, M Foltyn, M Lichovníková and A Musilová. 2013. Effect of protease supplementation of low protein broiler diets on growth parameters and carcass charateristic. Mendelnet 2013:268 - 272.

Rezaeipour V and S Gazani. 2014. Effects of feed form and feed particle size with dietary Lthreonine supplementation on performance, carcass characteristics and blood biochemical parameters of broiler chickens. Journal of Animal Science and Technology 2014, 56:20.

Sudjatinah $\mathrm{CH}$, Wibowo and Widyaningrum. 2005. The effect of papain extract on broiler performance. J.Indo.Trop.Anim.Agric, 30:224228.

Vieira SL, CR Angel, DJA Miranda, A Favero, RFA Cruzand and JOB Sorbara.2013. Effects of a monocomponent protease on performance and protein utilization in 1- to 26-day-of-age turkey poults. J. Appl. Poult. Res. 22:280-688.

Widjastuti T. 2009. The Use of Carica papaya Leaf Meal to Increase of The Production and Quality of Sentul Chicken Eggs. J. Agroland. 16(3):268273.

Yadav YL and RDSah. 2006. Supplementation of corn-soybean based layer diets with different levels of acids protease. J. Inst. Agric. Anim. Sci. 27:93-102.

Zohair GAM, GA Al-Maktari and MM Amer. 2012. A Comparative Effect of Mash and Pellet Feed on Broiler Performance and Ascites at High Altitude (Field Study). Global Veterinaria. 9(2):154-159. 